The International Journal of Indian Psychology

ISSN 2348-5396 (e) | ISSN: 2349-3429 (p)

Volume 3, Issue 4, No. 68, DIP: 18.01.207/20160304

ISBN: 978-1-365-39398-3

http://www.ijip.in | July-September, 2016

\title{
A Psycho - Analytical Study of Attitude towards Dowry among College Boys and Girls
}

\author{
Dr. Latika Varma ${ }^{1 *}$, Ankita Kumari ${ }^{2}$
}

Keywords: Dowry, Anxiety, Neuroticism, Psychoticism, Extrovert, Introvert

Dowry is a kind of gift which is given by bride's family in the form of durable goods, cash and movable-immovable property to her husband and his family on the occasion of marriage. According to : vacabulary.com - " In some cultures, the bride or her family pays a certain amount of money or property to the groom when a couple is married. This payment is called dowry". Britannica.com (2015) - "Dowry is the money, goods or estate that a woman brings to her husband or his family in marriage”.

Harbilas sarda - "The money which is given by parents to bride-groom is called gift, but when it crosses its certain limit is called dowry". Dowry system is continuing since ancient time in all over the world specially in India. This is a very serious problem for us. Dowry Death is seen. Instead of a happy married life, they choose death. This is the main cause of female infanticide and domestic violence. Radhika R.H. (2011) - "An Autopsy study of socio-etiological aspects in dowry death cases" unnatural deaths of married women amongst the total female deaths have been an increasing trend in Indian Society during the recent past year which may be suicide, homicide or even accidents".

According to her research; Most of dowry death victims' women age was 18-25 years, their duration of married life Were 2 years, they were from nuclear family and they lost their life by hanging herself". "Action Research on Dowry and Extreme Poverty": khutamara union, Bangladesh (2009) - The research established that dowry was a practice that is deep-rooted in society, becoming engrained in tradition in a relatively short period of time. Certain respondents strongly felt that without dowry it was impossible to arrange a marriage. Above researches shows that dowry system badly affects the society. This is one of the worst evil cultures of the society. Females are always exploited because of dowry. Atrocious incidents such as bride

\footnotetext{
${ }^{1}$ Associate Professor, P.G. Deptt. of Psychology, M. M. Mahila College, Ara, Bihar, India

${ }^{2}$ NET qualified, Ph.D. Scholar, Deptt. of Psychology, Veer Kunwar Singh University, Ara, Bihar, India *Responding Author

(C) 2016, L Varma, A Kumari; licensee IJIP. This is an Open Access Research distributed under the terms of the Creative Commons Attribution License (http://creativecommons.org/licenses/by/2.0), which permits unrestricted use, distribution, and reproduction in any Medium, provided the original work is properly cited.
} 


\section{A Psycho - Analytical Study of Attitude towards Dowry among College Boys and Girls}

burning, mental tortures, physical violence, suicide etc. are increasing day by day in the society. The ratio of girls is decreasing because of dowry. Dowry is the reason of stress and anxiety in girls.

They think that they can't be married to the eligible groom until their Parents don't Pay much dowry. Dowry is also the reason of illiteracy in girls. Parents think if they educate their daughter, they will have to pay much dowry for her level of groom. Many parents take loan for the dowry of their daughters which is degrading their life standard. This system should be completely stopped from the society. The governments of different countries have made rules and regulation to stop dowry but these are not working properly. The present research has been done on college boys and girls to know their attitude towards dowry. Attitude is affected by different variables such as personality traits, personal character, family background etc. In this research the effect of anxiety, security, insecurity, extrovert-introvert personality, inhabitation, caste, nature of family has been seen on attitude towards dowry. Thus this is a Psychoanalytical study.

Anxiety - Anxiety means unpleasant feeling of fear and apprehension. In other words it means a feeling of worry, nervousness or low feeling about something with an uncertain outcome. American Psychological Association (APA) - “Anxiety is an Emotion characterized by feeling of tension, worried thoughts and physical changed like increased blood pressure”.

Security-Insecurity - Security-Insecurity is a personality trait. A person who feels secure with himself is much more likely to achieve success, have meaningful relationships and be respected by others. But the person who feels insecure find difficulty in many aspects of life.

Extrovert-Introvert Personality - The people, who have Extrovert Personality, have interest in outer world. They do social work. They have lot of friends and have faith on others. They accept new rules very easily. On the other side the people who have introvert Personality have interest in their own world. They are confined to imaginative world. They have only few friends. They like to follow old rules.

Neuroticism - People who are neurotic, always suffer from anxiety. They have limited interest. They depend on another person and have frustration in life. They do nervous behavior and have frequent feeling of fear or worry. Eyesenck believed this the basis for all human personalities, and each person has varying degrees of each of these qualities. Neuroticism refers to the general liability of a person.

Psychoticism - This is defined by Eyesenk as a personality trait that is prone to take risks, might engage in anti-social behaviours, impulsiveness or non-conformist behavior. Psychoticism refers to a personality trait present in varying degrees in all persons. The people who suffer from psychoticism can't do their work properly. They are far away from reality. Their memory is also weak.

Inhabitation - Inhabitation refers to the living place of people. It includes urban and rural. The people who live in cities are called urban and who live in village are called rural. 


\section{A Psycho - Analytical Study of Attitude towards Dowry among College Boys and Girls}

Caste - Every Society has different castes. Some castes are in high position, these are called forward caste and some castes are in low position these are called backward caste. There are also other castes except forward and backward.

Nature of family - There are two types of family. Nuclear family and joint family. When only parents and their children live together are called nuclear family. On other hand when parents their brother-sister and grant parents with their children live together are called joint family.

Above all variables can affect the attitude of boys and girls towards dowry. Lot of researches has been done on dowry. Deepa Ghosh (2013), “Attitude towards dowry: comparison between boys and girls college student, Employed and unemployed male persons of Tripura, India”. According to this research all group (Boys, girls, employed, unemployed) Possess favourable attitude towards dowry. Chandrika Bose (2015),” The relationship between Dowry and Poverty” - This research has been shown that moderately poor families struggle to raise dowry through several different mechanism, including taking multiple loans from micro finance institutions or by selling assets including land. Afra Rahman Choudhury, Brown university (2001) "Money and Marriage : The Practice of Dowry and Bride price in rural India” - One important aspect characterzing marriages in India is financial transfer made at the time of marriage between families involved. These transfers can go in both directions - from the bride's family to the groom's known as dowry and vice versa, known as bride price. Dowry and bride price has been analysed as interdependent institutions, using retrospective data from the rural economic and demographic survey 1998. A nationally representative survey of rural India. Soumyanetra Munshi, (2014) - “Arranged Marriage, Education and dowry : A contract theoretic perspective”This paper propounds a contract theoretic model where dowry acts is a screening device to differentiate grooms of varying qualities. In 'arranged' marriage settings that are characterized by incomplete information in the sense that true quality of the groom remaining unobservable to the bride and in the presence of observable traits like education that are easier for the better quality groom to achieve, education-dowry contracts can Potentially serve a screening instrument”.

Thus this is clear that dowry system is Present in different countries of the world. It hampers the development of the society. It must be prohibited we should Promote inter-caste and inter religion marriage to get rid of this evil culture.

\section{Objective}

1. To measure the attitude towards dowry system among college boys and girls.

2. To measure the attitude towards dowry on the basis of family background and personal character of sample.

3. To measure the attitude towards dowry system on the basis of personality traits of sample. 


\section{A Psycho - Analytical Study of Attitude towards Dowry among College Boys and Girls}

\section{Hypothesis}

1. There would be significant difference among boys and girls in terms of attitude towards dowry.

2. Inhabitation would affect the attitude towards dowry among boys and girls.

3. Nuclear family would have positive attitude towards dowry than joint family.

4. Father's education would affect the attitude towards dowry among boys and girls.

5. Forward caste would have more Positive attitude towards dowry than backward caste.

6. There would be significant difference on attitude towards dowry among boys and girls in terms of anxiety.

7. There would be significant difference on attitude towards dowry among boys and girls in terms of security and Insecurity.

8. Extrovert personality would have positive attitude towards dowry than introvert personality.

9. High neurotic sample would have negative attitude towards dowry than low neurotic.

10. There would be significant difference between boys and girls of attitude towards dowry in terms of Psychoticism.

\section{METHOD}

\section{Sample}

200 college boys and girls (100 boys \& 100 girls) whose age range were 18-12 years had been selected from H.D.Jain College, Maharaja College and M.M. Mahila College, Ara, state-Bihar, (India). Samples were selected by purposive sampling method.

Tools - A Personal data schedule and 4 another scales were used for collection of data.

(1) Personal data schedule (PDS) - A short PDS was used to get essential information about college boys and girls such as sex, Age, Inhabitation, caste, Father's education etc.

(2) Attitude Towards Dowry Scale (ATDS) - This scale has been produced by Dr. Ramesh sharma. It was used in this research to measure the attitude of boys and girls towards dowry system. This scale is based on Likert scale. It has 24 statements. The reliability and validity of this scale is higher.

(3) Taylor's Manifest Anxiety Scale (TMAS) - This scale was used to measure the level of Anxiety of the Sample. This is the revised (1953) form of Taylor's scale. It has 50 statements and every statement has two options - true and false. It has also a scoring key.

(4) Security-Insecurity Inventory (S-I) - This scale was used to measure the level of insecurity of boys and girls. This inventory has been developed by Maslow. It has 75 items and every item has three options - Yes, No and P. It has also a scoring key.

(5) Eysenck Personality Questonnaire (EPQ) - The Hindi conversion of EPQ, which was done by Jahan 1984, was used to measure the three dimensions of personality-

(a) Exatraversion, (b) Neuroticism, (c) Psychoticism. It has 77 items. Every items has two options - yes and No. It has scoring key. The reliability and validity of this scale is very high.

(C) The International Journal of Indian Psychology, ISSN 2348-5396 (e)| ISSN: 2349-3429 (p) | 154 


\section{A Psycho - Analytical Study of Attitude towards Dowry among College Boys and Girls}

\section{Procedure}

Data collection was taken in a small group of 20-30 samples in the class room. Samples were made to intimate the aims and characters of the research and made rapport with them. Data collection was taken in two sessions. In 1st session PDS, ATDS \& TMAS were administered and in 2nd Session EPQ and SI inventory were administered. 45 minutes were given between two sessions for rest. Data was changed into tables and t-test, chi-squares, Product moment correlation were used for treatment of data.

\section{RESULT AND DISCUSSION}

The obtained results have been Presented in tables given below.

Table - 1, Sex difference in Attitude towards dowry

\begin{tabular}{|l|c|l|l|l|l|}
\hline Group & $\mathbf{N}$ & Mean & S.D & t value & P value \\
\hline Boys & 100 & 62.37 & 12.21 & 6.24 & 0.01 \\
\hline Girls & 100 & 54.88 & 11.76 & & \\
\hline
\end{tabular}

Above table shows that boys got more score on Attitude towards dowry scale in comparison of girls. t-value is significant on .01 level. This is clear that boys have more positive attitude towards dowry than girls. Thus hypothesis is Proved.

Table - 2, Comparison of the subject Inhabitation in terms of their Attitude towards dowry

\begin{tabular}{|c|c|c|c|c|}
\hline \multirow{3}{*}{ Group } & & \multicolumn{2}{|c|}{ Inhabitation } & \multirow{2}{*}{ chi-square } \\
\cline { 2 - 4 } & & Rural & Ubran & \\
\hline \multirow{3}{*}{ Boys } & High & 50 & 68 & \\
\cline { 2 - 4 } & & $(42.37)$ & $(57.63)$ & \multirow{2}{*}{5.04} \\
\cline { 2 - 4 } & Low & 58 & 34 & \\
\cline { 2 - 4 } & & $(58.54)$ & $(41.46)$ & \\
\hline \multirow{3}{*}{ Girls } & High & 40 & 57 & \multirow{2}{*}{5.77} \\
\cline { 2 - 4 } & & $(42.55)$ & $(57.45)$ & \\
\cline { 2 - 4 } & Low & 28 & 78 & \\
\cline { 2 - 4 } & & $(26.41)$ & $(73.58)$ & \\
\hline
\end{tabular}

$\mathrm{X}^{2} 5.04$ df $1 \mathrm{P}$ less than .05

$\mathrm{X}^{2} 5.77$ is also significant.

Above table shows that more boys (57.63\%) are from urban area and have Positive attitude towards dowry and urban girls have negative attitude. Thus hypothesis is proved that inhabitation affects the attitude of boys and girls.

(c) The International Journal of Indian Psychology, ISSN 2348-5396 (e)| ISSN: 2349-3429 (p) | 155 


\section{A Psycho - Analytical Study of Attitude towards Dowry among College Boys and Girls}

Table - 3, Comparison of subjects Nature of family in terms of their Attitude towards dowry

\begin{tabular}{|c|c|c|c|c|}
\hline \multirow{2}{*}{ Group } & & \multicolumn{2}{|c|}{ Nature of Family } & chi-square \\
\hline & & Joint & Nuclear & \\
\hline \multirow{4}{*}{ Boys } & High & 45 & 73 & \multirow{4}{*}{14.86} \\
\hline & & (38.14) & (61.86) & \\
\hline & Low & 54 & 28 & \\
\hline & & (65.85) & (34.15) & \\
\hline \multirow{4}{*}{ Girls } & High & 37 & 57 & \multirow{4}{*}{10.44} \\
\hline & & $(39.36)$ & $(60.64)$ & \\
\hline & Low & 66 & 40 & \\
\hline & & $(62.26)$ & $(37.76)$ & \\
\hline
\end{tabular}

$X^{2} 14.86 \& 10.44$ are significant.

Above table shows that nuclear family have more Positive attitude towards dowry than joint family. Thus hypothesis is proved.

Table - 4, Comparison of Education of subject's Father in terms of their Attitude towards dowry

\begin{tabular}{|c|c|c|c|c|}
\hline \multirow{3}{*}{ Group } & & \multicolumn{2}{|c|}{ Educational level } & \multirow{2}{*}{ chi-square } \\
\cline { 2 - 4 } & & Under Graduate & Graduate & \\
\hline \multirow{3}{*}{ Boys } & High & 69 & 49 & \multirow{3}{*}{8.26} \\
\cline { 2 - 4 } & & $(58.47)$ & $(41.53)$ & \\
\cline { 2 - 4 } & Low & 31 & 51 & \multirow{2}{*}{8.02} \\
\cline { 2 - 4 } & & $(37.80)$ & $(62.20)$ & \\
\hline \multirow{3}{*}{ Girls } & High & 57 & 37 & \\
\cline { 2 - 4 } & & $(60.64)$ & $(39.36)$ & \\
\cline { 2 - 4 } & Low & 43 & 63 & \\
\cline { 2 - 4 } & & $(40.57)$ & $(59.43)$ & \\
\hline
\end{tabular}

Above table shows that Boys and girls whose fathers were under-graduate have positive attitude towards dowry. Thus hypothesis is proved.

(C) The International Journal of Indian Psychology, ISSN 2348-5396 (e)| ISSN: 2349-3429 (p) | 156 
A Psycho - Analytical Study of Attitude towards Dowry among College Boys and Girls

Table - 5, Comparison of the subject's caste in terms of their attitude towards dowry

\begin{tabular}{|c|c|c|c|c|c|}
\hline \multirow{3}{*}{ Group } & & \multicolumn{3}{|c|}{ Caste } & chi-square \\
\cline { 2 - 5 } & & Forward & Backward & others & \\
\hline \multirow{3}{*}{ Boys } & High & 68 & 31 & 19 & \\
\cline { 2 - 5 } & & $(57.63)$ & $(26.27)$ & $(16.10)$ & \multirow{2}{*}{1.27} \\
\cline { 2 - 5 } & Low & 52 & 16 & 14 & \\
\cline { 2 - 5 } & & $(63.41)$ & $(19.51)$ & $(17.07)$ & \\
\hline \multirow{3}{*}{ Girls } & High & 54 & 22 & 18 & \multirow{2}{*}{0.26} \\
\cline { 2 - 5 } & & $(57.45)$ & $(23.40)$ & $(19.15)$ & \\
\cline { 2 - 5 } & Low & 58 & 28 & 20 & \\
\cline { 2 - 5 } & & $(54.72)$ & $(26.41)$ & $(18.87)$ & \\
\hline
\end{tabular}

$\mathrm{X}^{2}$ is not significant.

Thus hypothesis is not proved.

Table - 6, Comparison of the high and low scores on Attitude towards dowry scale in terms of their levels of Anxiety

\begin{tabular}{|c|c|c|c|c|c|c|}
\hline Group & & $\mathrm{N}$ & Mean & S.D. & t-value & P value \\
\hline \multirow{2}{*}{ Boys } & High & 59 & 18.32 & 9.37 & \multirow{2}{*}{1.33} & \multirow{2}{*}{ N.S. } \\
\cline { 2 - 5 } & Low & 41 & 20.11 & 9.41 & & \\
\hline \multirow{2}{*}{ Girls } & High & 47 & 18.73 & 9.93 & \multirow{2}{*}{2.45} & \multirow{2}{*}{0.05} \\
\cline { 2 - 5 } & Low & 53 & 21.24 & 10.08 & & \\
\hline
\end{tabular}

Table - 7

\begin{tabular}{|c|c|c|c|c|}
\hline Group & $\mathrm{N}$ & $\mathrm{r}$ & $\mathrm{df}$ & $\mathrm{P}$ value \\
\hline Boys & 100 & .39 & 98 & .01 \\
\hline Girls & 100 & .30 & 98 & .01 \\
\hline
\end{tabular}

Above table shows that Attitude towards dowry and level of anxiety have positive correlation.

Table - 8, Comparison between the high and low scores on Attitude towards Dowry scale in terms of their scores on S.I. Inventory

\begin{tabular}{|c|c|c|c|c|c|c|}
\hline Group & & $\mathrm{N}$ & Mean & S.D. & t-value & P value \\
\hline \multirow{2}{*}{ Boys } & High & 59 & 36.03 & 10.77 & 5.64 & \multirow{2}{*}{01} \\
\cline { 2 - 6 } & Low & 41 & 27.54 & 10.34 & & \\
\hline \multirow{2}{*}{ Girls } & High & 47 & 32.63 & 11.63 & 4.05 & \multirow{2}{*}{01} \\
\cline { 2 - 6 } & Low & 53 & 26.27 & 10.45 & & \\
\hline
\end{tabular}

(c) The International Journal of Indian Psychology, ISSN 2348-5396 (e)| ISSN: 2349-3429 (p) | 157 


\section{A Psycho - Analytical Study of Attitude towards Dowry among College Boys and Girls}

Table 8 shows that boys and girls who got high scores on ATDS have also got high scores on S.I Inventory. Thus this is clear that boys and girls who feel insecure have positive attitude towards dowry.

Product moment correlation was used to know correlation between both data.

Table - 9, Relation between Attitude towards dowry and security Insecurity-

\begin{tabular}{|c|c|c|c|c|}
\hline Group & $\mathrm{N}$ & r value & $\mathrm{df}$ & $\mathrm{P}$ value \\
\hline Boys & 100 & .21 & 98 & .05 \\
\hline Girls & 100 & .27 & 98 & .01 \\
\hline
\end{tabular}

Boy r.21 df 98 p less than .05 and girls r.27 df 98 p less than .01

Above table shows that there is positive and significant correlation between attitude towards dowry and Psychological Insecurity. Thus hypothesis is proved.

Table - 10, Comparison of the high and low scores on ATDS in terms of their Extraversion scores

\begin{tabular}{|c|c|c|c|c|c|c|}
\hline Group & & $\mathrm{N}$ & Mean & S.D. & t-value & P value \\
\hline \multirow{2}{*}{ Boys } & High & 59 & 12.76 & 8.71 & \multirow{2}{*}{2.46} & \multirow{2}{*}{.05} \\
\cline { 2 - 6 } & Low & 41 & 9.45 & 7.34 & & \\
\hline \multirow{2}{*}{ Girls } & High & 47 & 13.78 & 8.13 & \multirow{2}{*}{3.89} & \multirow{2}{*}{.01} \\
\cline { 2 - 6 } & Low & 53 & 10.29 & 9.74 & & \\
\hline
\end{tabular}

Above table shows that boys and girls who have extrovert Personality have positive attitude towards dowry.

Table - 11, Relationship between Attitude towards Dowry and Extraversion

\begin{tabular}{|c|c|c|c|c|}
\hline Group & $\mathrm{N}$ & r value & $\mathrm{df}$ & P value \\
\hline Boys & 100 & .22 & 98 & .05 \\
\hline Girls & 100 & .31 & 98 & .01 \\
\hline
\end{tabular}

Result table shows that there is positive and significant correlation between attitude towards dowry and extraversion. Thus hypothesis is proved.

(C) The International Journal of Indian Psychology, ISSN 2348-5396 (e)| ISSN: 2349-3429 (p) | 158 
A Psycho - Analytical Study of Attitude towards Dowry among College Boys and Girls

Table - 12, Comparison of the high and low scores on ATD scale in terms of their Neuroticism scores

\begin{tabular}{|c|c|c|c|c|c|c|}
\hline Group & & $\mathrm{N}$ & Mean & S.D. & t-value & P value \\
\hline \multirow{2}{*}{ Boys } & High & 59 & 13.04 & 10.18 & \multirow{2}{*}{.55} & \multirow{2}{*}{ N.S. } \\
\cline { 2 - 5 } & Low & 41 & 13.79 & 9.15 & & \\
\hline \multirow{2}{*}{ Girls } & High & 47 & 11.85 & 10.25 & \multirow{2}{*}{.89} & \multirow{2}{*}{ N.S. } \\
\cline { 2 - 5 } & Low & 53 & 13.09 & 9.17 & & \\
\hline
\end{tabular}

Above table shows that high and low scorers on ATD scale have not difference on their level of neuroticism t-value is also not significant.

Table - 13, Relationship between Attitude towards dowry and Neuroticism

\begin{tabular}{|c|c|c|c|c|}
\hline Group & $\mathrm{N}$ & r value & $\mathrm{df}$ & $\mathrm{P}$ value \\
\hline Boys & 100 & -.12 & 98 & $\mathrm{NS}$ \\
\hline Girls & 100 & -.09 & 98 & $\mathrm{NS}$ \\
\hline
\end{tabular}

Above table shows that there is no significant difference between Attitude towards dowry and Neuroticism. Thus hypothesis is not proved.

Table - 14, Comparison of the high and low scores on ATD scale in terms of their Psychoticism scores

\begin{tabular}{|c|c|c|c|c|c|c|}
\hline Group & & $\mathrm{N}$ & Mean & S.D. & t-value & P value \\
\hline \multirow{2}{*}{ Boys } & High & 59 & 10.28 & 9.26 & \multirow{2}{*}{.25} & \multirow{2}{*}{ N.S. } \\
\cline { 2 - 5 } & Low & 41 & 9.33 & 8.91 & & \\
\hline \multirow{2}{*}{ Girls } & High & 47 & 8.20 & 4.65 & \multirow{2}{*}{1.06} & \multirow{2}{*}{ N.S. } \\
\cline { 2 - 5 } & Low & 53 & 10.19 & 6.03 & & \\
\hline
\end{tabular}

Above table shows that the mean of Psychoticism scores is 10.28 of high scorer's boys on ATDS which is higher than the mean of low scorers $t$ value is not significant. On the other hand low scorer girls on ATDS have got more scores on psychoticism than high scorer girls t-value is also not significant.

Table - 15, Relationship between Attitude towards Dowry and Psychoticism

\begin{tabular}{|c|c|c|c|c|}
\hline Group & $\mathrm{N}$ & $\mathrm{r}$ value & $\mathrm{df}$ & $\mathrm{P}$ value \\
\hline Boys & 100 & .38 & 98 & .01 \\
\hline Girls & 100 & .11 & 98 & $\mathrm{NS}$ \\
\hline
\end{tabular}

Above table shows that boys' r.38, df 98 is significant on the level of .01 but girls' $r$ is not significant. Thus hypothesis is not proved.

(C) The International Journal of Indian Psychology, ISSN 2348-5396 (e) | ISSN: 2349-3429 (p) | 159 


\section{SUMMARY AND CONCLUSION}

The present study was done on 200 college boys and girls to know their attitude towards dowry, Attitude can be affected by different variables such as Inhabitation, nature of family, father's education, caste, anxiety, insecurity, extraversion neuroticism, psychoticism etc. So the effect of above variables was also seen on attitude towards dowry.

The general conclusions are below-

- In this research it was found that boys have more positive attitude towards dowry in comparison of girls. Boys get lot of benefit by dowry. So they support this system. Girls are exploited by this system. So they have negative attitude towards dowry.

- Inhabitation affects the attitude of boys and girls towards dowry. Boys who are from urban area have positive attitude but urban girls have negative attitude towards dowry. In urban area lot of things are sold in high prices. Generally urban people don't have not their own house in cities. So they have to pay large amount for rented house.

- They have to also bear too much travel fare. Their needs are high in comparison of rural people. So they have positive attitude towards dowry.

- Urban girls are highly educated, they stay at home and their parents fulfill their all desires. So they have negative attitude.

- It was found that boys and girls who belong to nuclear family have positive attitude towards dowry. Nuclear family has few earning members but joint family has more earning members and their economic condition is better than nuclear family.

- Boys and girls whose fathers are less educated have positive attitude towards dowry. Less educated fathers want to follow old rules. They suffer from superstition, so they support dowry. It affects the attitude of their children.

- Caste didn't affect the attitude of boys and girls towards dowry in this research.

- It was found that more anxious students have negative attitude towards dowry. Anxious person have more awareness towards government rules. They want to be free from anxiety.

- Students who feel insecure have positive attitude towards dowry. Money is only the sources which fulfills our desires and make the life comfortable. Rich people feel more secure than poor.

- Boys and girls who have extrovert personality have positive attitude towards dowry. Extrovert personality has trust in social rules and regulations.

- Neuroticism and Psychoticism did not affect the attitude of boys and girls towards dowry.

Thus this is clear that boys have more positive attitude towards dowry than girls. Students, who feel psychologically insecure, low anxious and have extrovert personality have positive attitude towards dowry.

They are from urban area, member of nuclear family and their fathers are less educated.

(C) The International Journal of Indian Psychology, ISSN 2348-5396 (e)| ISSN: 2349-3429 (p) | 160 


\section{A Psycho - Analytical Study of Attitude towards Dowry among College Boys and Girls}

\section{Acknowledgments}

The author appreciates all those who participated in the study and helped to facilitate the research process.

\section{Conflict of Interests}

The author declared no conflict of interests.

\section{REFERENCES}

Afra Rahman Choudhury, Brown University (2001): Money and Marriage: The practice of Dowry and Bride price in rural India.

Afra Rahman Choudhury, Brown University: Money and Marriage: The practice of Dowry and Bride price in rural India.

Ahuja S.P. (1982): Practice and problem of Dowry.

Chandrika Bose: The relationship between dowry and Poverty.

Deepa Ghosh: Attitude towards dowry : Comparison between boys and girls college student, Employed and unemployed male persons of Tripura, India.

Devi Hemlata (1983): Attitude on Dowry system

Dr. Ramesh Sharma: Attitude towards dowry scale.

Kane P.V. (1930): History of Dharma sastra; Ancient and Medieval.

Kapoor Jyotsana (1980): Social Report on Accident on Dowry Death.

Khutamara unioun, Bangladesh (2009): Action research on dowry and Extreme Poverty.

Margon Kenneth W. (1953) : The Religion of the Hindu.

Maslow A.H. (1952): The S.I. Test : A Measure of Psychological Security- Insecurity Inventory.

Radhika R.H. (2011): An Autopsy study of Socio-etiological aspects in dowry death cases.

Soumyanetra Munshi (2014): Arranged Marriage, Education and dowry: A contract theoretic perspective.

Taylor (1953): Revised Taylor’s Manifest Anxiety scale.

Thomas P. (1964): Indian women through the ages.

How to cite this article: L Varma, A Kumari (2016), A Psycho - Analytical Study of Attitude towards Dowry among College Boys and Girls, International Journal of Indian Psychology, Volume 3, Issue 4, No. 68, ISSN:2348-5396 (e), ISSN:2349-3429 (p), DIP:18.01.207/20160304, ISBN:978-1-365-39398-3 